\title{
Activity of crustal faults and the Xolapa sliver motion in Guerrero-Oaxaca forearc of Mexico, from seismic data
}

\author{
Ekaterina Kazachkina ${ }^{1 *} \mathbb{D}$, Vladimir Kostoglodov ${ }^{1}$, Allen Husker ${ }^{1}$ and Nathalie Cotte ${ }^{2}$
}

\begin{abstract}
Oblique convergent margins often host forearc slivers separated by the subduction interface and a trench parallel strike-slip fault system in the overriding plate. Mexican oblique subduction setting led to the formation of a forearc sliver and accomodation of part of the slip at the bounding system of strike-slip faults. The Xolapa sliver is, on average, a 105-km-wide crustal block located along the coast of Guerrero and Oaxaca states of Mexico, and is limited by a $\sim 650-\mathrm{km}$-long La Venta-Chacalapa fault zone. Two types of datasets, local catalog and Global CMT compilation, are used to estimate the motion of the Xolapa sliver using the rigid block model that describes the phenomenon of slip partitioning. According to the results obtained from local and Global CMT catalogs for selected subduction thrust earthquakes, the forearc sliver moves southeastwards with respect to the fixed North America plate at the rate of $10 \pm 1 \mathrm{~mm} /$ year and $5.6 \pm 0.8 \mathrm{~mm} /$ year, respectively. These velocities in general agree with the values obtained from long-term GPS observations ( $5-6 \mathrm{~mm} /$ year). The origin of the inconsistency between local and teleseismic estimates is attributed to a difference in the double couple focal mechanism parameters for two types of datasets. Convergence obliquity changes from $10.42^{\circ}$ and the rate of $58 \mathrm{~mm} /$ year to $13.29^{\circ}$ at the rate of $68 \mathrm{~mm} /$ year along the Guerrero and Oaxaca coast increasing from northwest to southeast; therefore, the Xolapa sliver is supposed to be stretched. However, the slip vector azimuths of thrust subduction earthquakes tend to approach plate convergence vectors southeastwards along the coast; so, we assume that this may produce the forearc block compression.
\end{abstract}

Keywords: Slip partitioning, Forearc sliver, Oblique subduction zone

\section{Introduction}

The phenomenon of forearc sliver motion has been observed in different subduction zones. In Sumatra, for example, around $60 \%$ of subduction obliquity is accommodated at the subduction interface, with about onethird transferred to the great strike-slip fault called the Great Sumatran Fault (GSF); the area between the GSF and the trench is referred to as the Sumatran Sliver (Diament et al. 1992). We observe a similar partitioning pattern in Ecuador and Colombia along the DoloresGuayaquil Fault zone (Ego et al. 1996) and in South Chile along the Liquiñe-Ofqui Fault that forms part of

\footnotetext{
*Correspondence: kazachkina@igeofisica.unam.mx

${ }^{1}$ Institute of Geophysics, National Autonomous University of Mexico, Mexico City, Mexico

Full list of author information is available at the end of the article
}

the 7000-km-long South American subduction zone (e.g., Cembrano et al. 1996; Wang et al. 2007; VillegasLanza et al. 2016). The study of Villegas-Lanza et al. (2016) defines a Peruvian Sliver as a block extending N-S between the Gulf of Guayaquil and the Altiplano of Peru and between the trench and the boundary between the Eastern Cordillera and the Western Cordillera in E-W direction. Ryan and Scholl (1989) observe that oblique subduction in the Aleutian arc created a major rightlateral shear zone, the Hawley Ridge shear zone, that has geomorphical and geophysical characteristics similar to the San Andreas fault in California. The southwest Kuril arc is characterized by strike-slip movement between the volcanic and frontal arcs, a graben at the northeastern end of the forearc, and collision at the southwestern margin of the forearc. These tectonic features suggest the southwestward migration of the Kuril forearc sliver 
(Kimura 1986). A previous attempt to identify a sliver on the Pacific forearc of Mexico and to estimate its velocity was presented in the paper of Ego and Ansan (2002).

The coast of the Southern Mexican states, Guerrero and Oaxaca, between $-102.0^{\circ} \mathrm{E}$ to $-95.5^{\circ} \mathrm{E}$ and $15.5^{\circ} \mathrm{N}$ $-18.0^{\circ} \mathrm{N}$ hosts a prominent geologic structure referred to as the Xolapa sliver. This crustal block (Fig. 1) is located along the Pacific coast of Mexico $\sim 650-\mathrm{km}$ long and $\sim 50-80-\mathrm{km}$ wide (Pérez-Gutiérrez et al. 2009) from the coast inland. The Xolapa sliver also includes $\sim 70 \mathrm{~km}$ from the trench to the coast. The contact of the Xolapa terrane with the neighboring terranes is complex. It accommodates both brittle and ductile faults, and parts of the boundary are interrupted by Cenozoic plutons (Ortega-Gutiérrez et al. 2014). The most prominent boundary structure is the La Venta-Chacalapa (LVC), left-lateral transtensional and normal ductile shear zone, which was active during the Eocene on the west (e.g., Riller et al. 1992; Solari et al. 2007) and the Oligocene in the east (Tolson 2005).

The convergence rate of Cocos (CO) plate with respect to the North America (NA) plate increases southeastwards from 58 to $68 \mathrm{~mm} /$ year [PVEL model, DeMets et al. (2010)] in the studied section of the Mexican subduction zone. Cocos-North America plate interface has large lateral variations in its dip, with a shallow subhorizontal segment bounded in Guerrero-Oaxaca area by segments that dip more steeply: $\sim 50^{\circ}$ near the Rivera-Cocos plate boundary and $\sim 30^{\circ}$ near the Isthmus of Tehuantepec (Pardo and Suarez 1995). The age of the oceanic Cocos plate subducting at the Middle America Trench (MAT) increases from about $10 \mathrm{Ma}$ in the west to about $23 \mathrm{Ma}$ (Manea et al. 2005) in the east (Pardo and Suarez 1995). The Cocos plate seafloor is irregularly covered with small- and medium-sized seamounts subducting under the coast of Guerrero and Oaxaca and delimited by Tehuantepec fracture zone in the south. While the Guerrero segment of the subduction zone is characterized by a relatively small number of seamounts with heights of $\sim 1 \mathrm{~km}$, the Oaxaca segment is covered with a large number of seamounts arranged in chains almost parallel to the convergence direction. These seamount chains significantly affect the morphology of the trench and the forearc (Kanjorski 2003). There are several

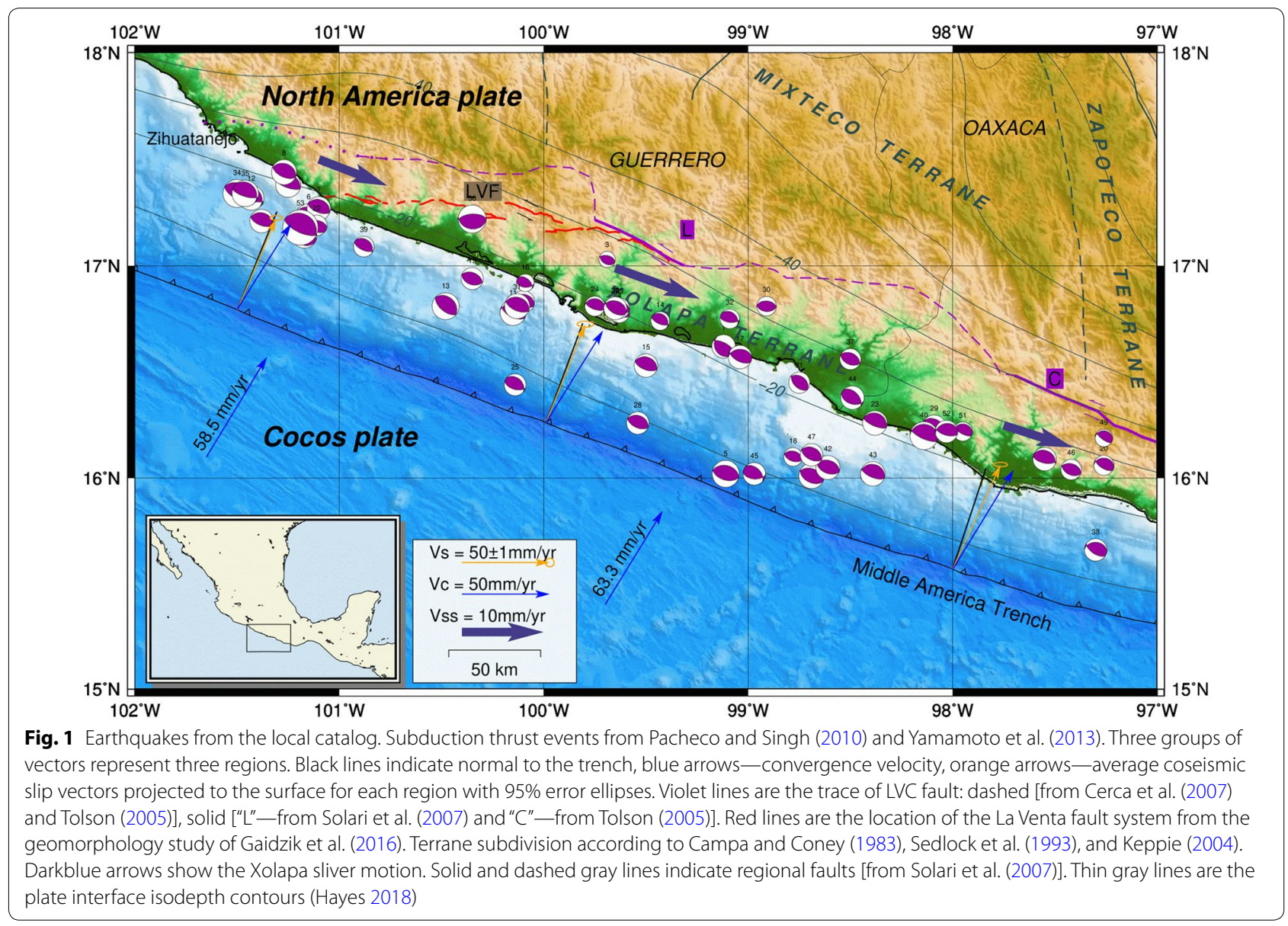


clusters of intense seismic activity, particularly in front of Oaxaca that correlate well with the location of seamounts on the incoming Cocos plate (Manea et al. 2017). This observation indicates a relationship between crustal seismicity and the subducting bathymetric structures.

The phenomenon of slip partitioning is observed along the coast of the Central and Southern Mexico. The forearc sliver is, on average, a 105-km-wide crustal block bounded at northeast by a $\sim 650-\mathrm{km}$-long LVC fault zone striking parallel to the MAT. This fault system accommodates most of the oblique component of convergence between the CO and NA plates. Long-term GPS observations show trench parallel motion of the sliver southeastwards at the rate of $6-8 \mathrm{~mm} /$ year with respect to the NA plate (Kostoglodov et al. 2016). This sliver geologically corresponds to the Xolapa complex and is composed by a sequence of high-grade metasedimentary and metaigneous rocks that are frequently intruded by both deformed and undeformed plutonic rocks. It is suggested that the Xolapa terrane is allochthonous, and was accreted to the continental margin of southern Mexico during Mesozoic-Tertiary (e.g., Corona-Chávez et al. 2006; Pérez-Gutiérrez et al. 2009). Present work analyses the slip partitioning phenomenon observed in oblique subduction zones applying the model of McCaffrey (1992) to the dataset of shallow thrust events on the subduction interface with $M_{\mathrm{w}}>3.6$ for the case of Mexico using regional and teleseismic data.

Sliver motion is explained by the slip partitioning at oblique convergent margins. Slip vectors of relatively shallow $(<60 \mathrm{~km})$ thrust earthquakes at oblique subduction zones often lay between the normal to the trench axis and the vector of relative plate convergence (McCaffrey 1992), suggesting that oblique convergence is partially decoupled. This means that at the trench, a percentage of arc-parallel motion of the leading edge of the upper plate shows less oblique thrusting. Partial decoupling is represented by separating slip vectors from thrust earthquakes into slip on strike-slip faults parallel to the trench and slip on the thrust interface (McCaffrey 1992).

The Mexican subduction zone stands out among other subduction zones with a unique subducting slab geometry that plays a role in shear stress distribution. The seismogenic zone extends up to $81 \mathrm{~km}$ from the trench and is followed by a wide shallow subhorizontal plate interface at the distance between 115 and $270 \mathrm{~km}$ from the trench beneath the Guerrero state (e.g., Kostoglodov et al. 1996; Pérez-Campos et al. 2008) at depth of $\sim 45 \mathrm{~km}$. This part of the subduction interface hosts the transition zone that is characterized by slow slip events (SSE) and non-volcanic tremors (NVT). The remotest NE inland section of the subduction interface is in a stable sliding. This particular configuration of the young subducting
Cocos plate $(\sim 14-16 \mathrm{Ma})$ apparently creates some distinct geodynamic consequences, such as thin continental lithosphere, relatively shallow intraslab seismicity and an unusual outlying position of the volcanic front (Manea et al. 2004). It can also have an effect on the stress and strain distribution in the forearc and as a consequence on the activity of the LVC fault system. At small angles of convergence obliquity such geometrical setting of the subduction interface, with an increased contact area between oceanic and continental crust, creates favorable conditions for the sliver motion.

The results obtained in this work confirm that the Xolapa sliver is active and its sinistral (with respect to the NA fixed plate) motion agrees well with the GPS estimates of velocities on the left-lateral strike-slip fault system bounding the Xolapa terrane. Nevertheless, our analysis of local and global CMT catalogs with carefully selected subduction thrust events shows that calculated average rates of the sliver motion are fairly different. Therefore, the principal objective of this paper is to assess sliver rates applying McCaffrey (1992) model and apprise the sources of this difference.

\section{Data and methods}

The data (focal mechanisms) obtained by local seismic networks and analyzed in several previous studies of Pacheco and Singh (2010), Yamamoto et al. (2013) and events localized and analyzed by National Seismologic Service (Mexican SSN http://www.ssn.unam.mx/) are used in this work. The study area includes 53 thrust earthquakes from local catalog (see Additional file 1). Selected events should be the subduction thrust earthquakes on the plate interface presumably satisfying the following criteria similar to those of Ego and Ansan (2002): plunge of the tension axis $>45^{\circ}$, angle between the event strike and local trench azimuth $<30^{\circ}$, depth $<60 \mathrm{~km}$ and direction of the rake is downdip along the subduction interface.

Three regions $\left(-102.0^{\circ} \mathrm{E}\right.$ to $-101.0^{\circ} \mathrm{E},-101.0^{\circ} \mathrm{E}$ to $-99.0^{\circ} \mathrm{E}$ and $-99.0^{\circ} \mathrm{E}$ to $-97.0^{\circ} \mathrm{E}$ ) are analyzed separately. Weighted mean coseismic slip vector for the events from the local catalog is computed for each region. The weights are assigned based on the seismic moment released $\left(M_{0}\right)$ assuming that parameters of the events with bigger $M_{0}$ are defined more precisely (DeMets 1992). Figure 1 shows mean coseismic slip $\bar{V}_{\mathrm{s}}$ with respect to the trench normal $T_{\mathrm{n}}$ and convergence rate $V_{\mathrm{c}}$ between the $\mathrm{CO}$ and NA plates. Convergence direction and rate are computed using the PVEL model (DeMets et al. 2010). Trench normal is the direction measured perpendicular to the local strike of the trench (DeMets 1992). The trench is approximated with the small circle with the pole at $-80.11^{\circ} \mathrm{E}, 51.01^{\circ} \mathrm{N}$ and radius of 
$4256.734 \mathrm{~km}$. Trench normal lays in the direction to the pole of the small circle (Fig. 2).

Selected data from the Global CMT catalog for thrust events in 1976-2016 are analyzed for the same area (Fig. 3) and compared to the results from the local catalogs. 83 events with $M_{\mathrm{w}} \geq 4.7$ have been selected. Selection criteria are the same as for the local catalog. Additionally only the events with percentage of double couple DC $\geq 80 \%$ are considered (see Additional file 2). The area is divided into three regions (Fig. 3).

The rigid block model developed by McCaffrey (1992) is used in this work to quantify the Xolapa sliver motion and corresponding strike-slip displacement on the LVC fault. Transcurrent motion at the LVC fault can be estimated from slip vectors of subduction thrust earthquakes occurring on the plate interface. Following the model of McCaffrey (1992), the Xolapa sliver and NA and CO plates are assumed to be a system of rigid blocks (no change of shape or size in time and no change of mass) on a spherical earth. The velocity vector of the subducting plate relative to the fixed upper plate has a magnitude $V_{\mathrm{c}}$ and forms an angle $\gamma$ (obliquity) in the horizontal plane relative to the trench normal, $T_{\mathrm{n}}$. The relative motion is partially accommodated by slip on the subduction interface and slip on the trench-parallel crustal strike-slip faults. Thus, the inland system of echelon faults isolates a third block of lithosphere, called sliver (Fig. 4). The model assumes that (1) the motions of the blocks are resisted only on the two bounding faults (i.e., the three plates are rigid) and the faults will slip when stress on them reaches a maximum yield stress; (2) the problem is twodimensional so that there is no variation in stress in the $x$ direction (parallel to strike of the trench); (3) forces are in equilibrium (excluding a short time during earthquakes

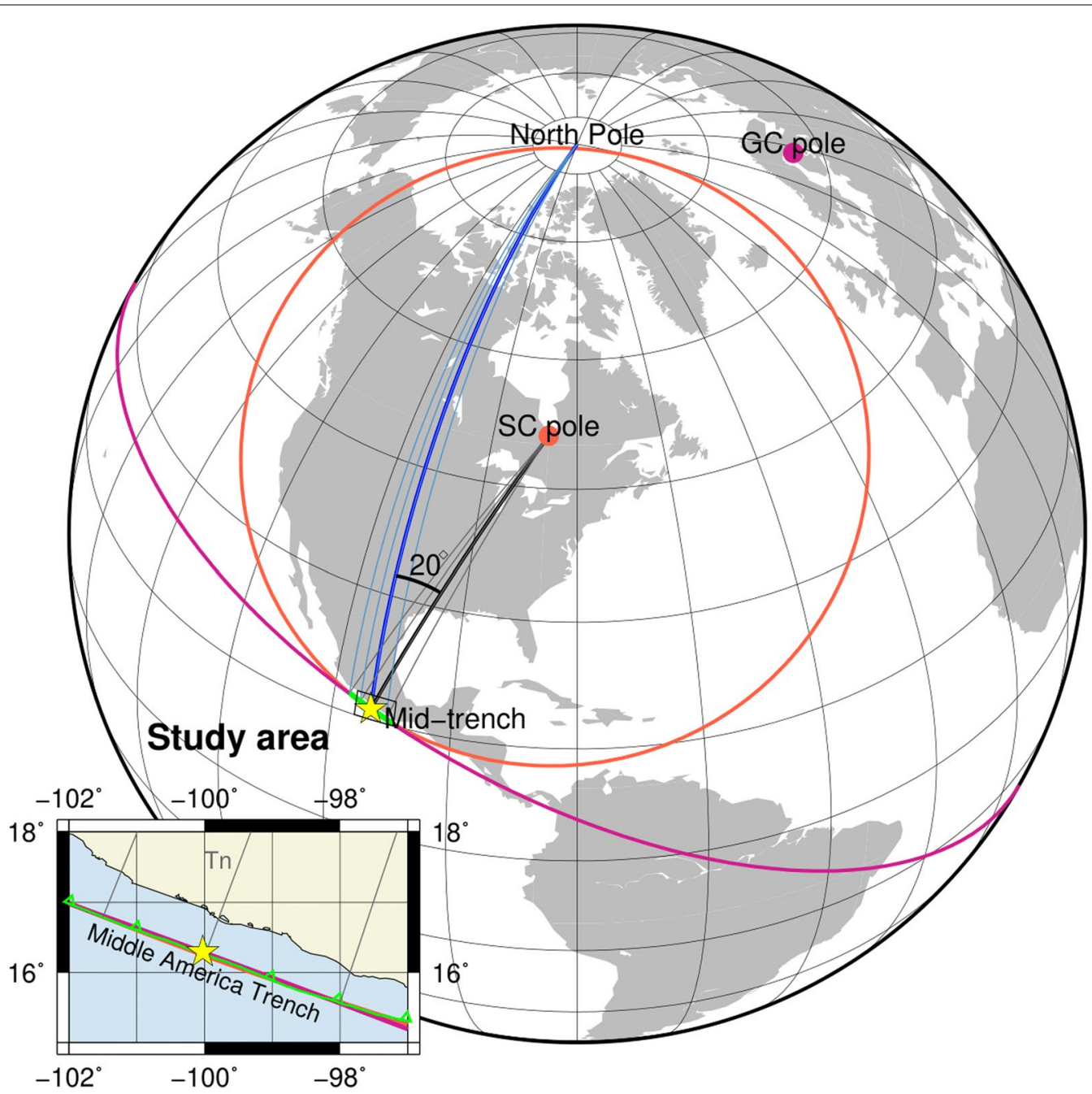

Fig. 2 Trench approximation. Great (GC) and small (SC) circles computed to approximate the trench section in Guerrero and Oaxaca. The SC approximation fits the MAT better. Blue line is the direction to the North, gray lines - trench normals $\left(T_{n}\right)$ 


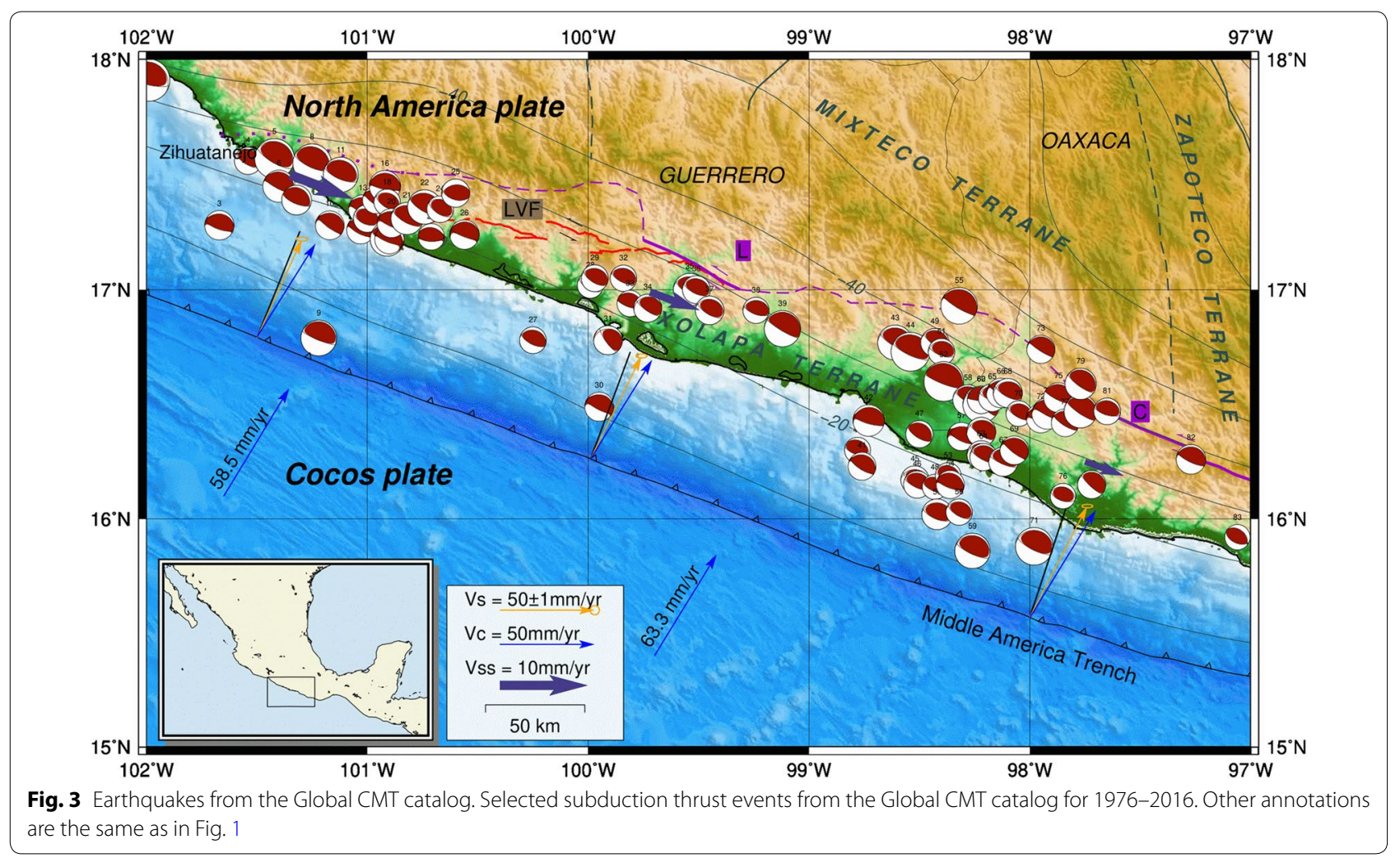

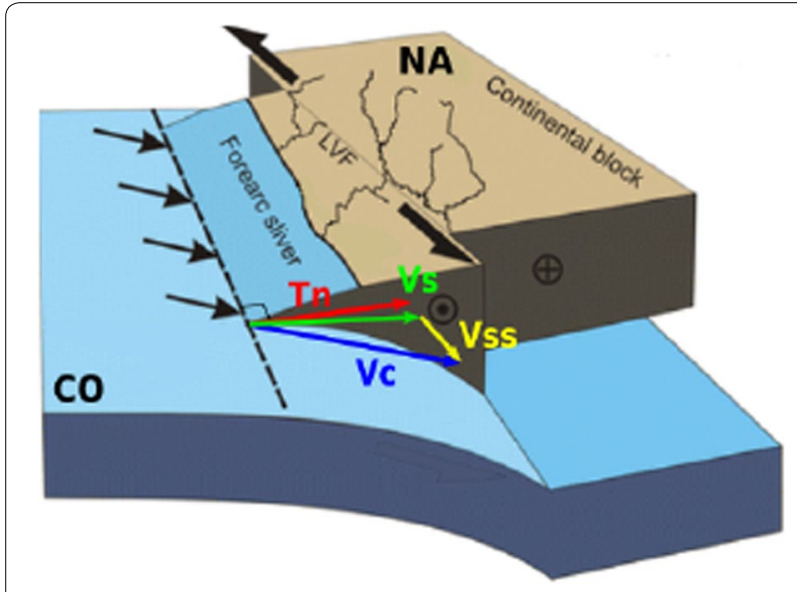

Fig. 4 Forearc sliver. Relative motion of the NA and CO tectonic plates is partially accommodated by slip on the subduction interface and slip on the La Venta-Chacalapa (LVF) system of trench-parallel crustal strike-slip faults. $V_{c}$-velocity vector of the subducting plate relative to the fixed upper plate; $T_{n}$ — trench normal; $V_{s}$-surface projection of the coseismic slip vector for subduction thrust earthquakes; $V_{s s}=$ forearc sliver velocity. Black arrows indicate direction of convergence; black half-arrows show sinistral motion at the LVF [Modified from Gaidzik et al. (2016)] when accelerations occur); (4) no body forces act in the $x$ direction; and (5) the stresses are considered vertically integrated. The vertical extents of the thrust and strikeslip faults are allowed to differ (McCaffrey 1992).

Coseismic slip vectors $V_{\mathrm{s}}$ of the thrust earthquakes lay between the trench normal $T_{\mathrm{n}}$ and the vector of convergence, $V_{\mathrm{c}}$, and forms an angle $\psi$ with the trench normal (Fig. 5). Therefore,

$$
V_{\mathrm{s}}=\frac{V_{\mathrm{c}} \cos \gamma}{\cos \psi}
$$

where $V_{\mathrm{c}}$ is the rate of oblique convergence. The strikeslip vector is then obtained as (McCaffrey 1992)

$$
V_{\mathrm{ss}}=V_{\mathrm{c}} \sin \gamma-V_{\mathrm{c}} \cos \gamma \tan \psi
$$

The values of $V_{\mathrm{sS}}$ are compared for the teleseismic and regional seismicity catalogs. Both catalogs provide information on the earthquake parameters (epicenter location, strike, dip and rake). The earthquake focal mechanism parameters are used to calculate $\gamma$ and $\psi$ by applying axes rotations. 


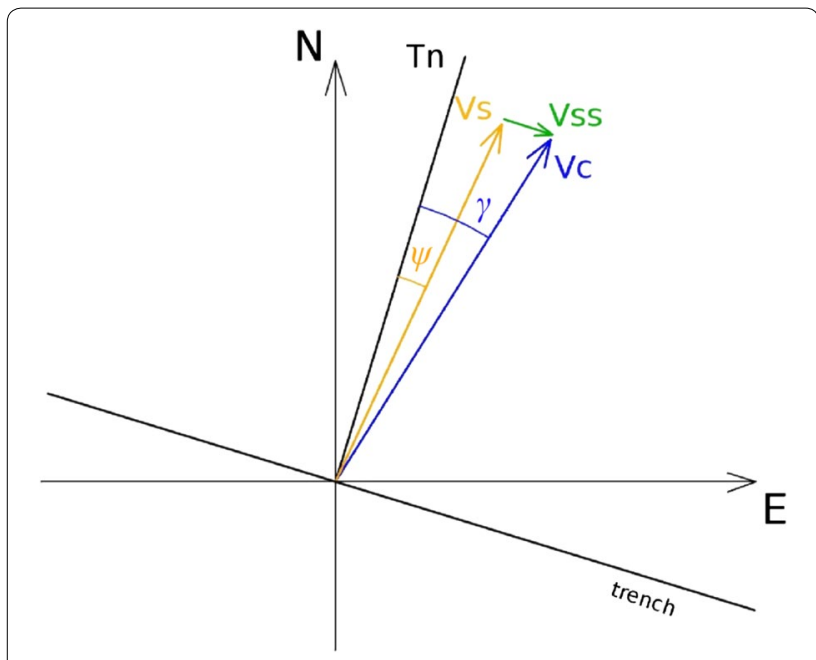

Fig. 5 Schematic representation of oblique subduction system kinematics. Black line $\left(T_{n}\right)$-normal to the trench, blue arrow $\left(V_{c}\right)$ convergence velocity vector, orange arrow $\left(V_{s}\right)$ - coseismic slip vector, green arrow $\left(V_{S s}\right)$-strike-slip component, $\gamma$-convergence obliquity, $\psi$-subduction obliquity

The rigid-body model allows for an approximation of the forearc strike-slip motion through simple geometrical calculations, furthermore, $\tan \psi$ characterizes average friction coefficient on the sliver bounding fault (Haq and Davis 2010).

\section{Results}

Figure 5 shows the model of sliver motion along oblique convergence margin (McCaffrey 1992). Based on the difference between azimuths of the coseismic slip vector $\left(V_{\mathrm{s}}\right)$ and convergence vector $\left(V_{\mathrm{c}}\right)$, we can infer information about slip partitioning. By doing so we determine the presence of forearc sliver motion with respect to the continental plate (Eq. 2). Model parameters that describe this motion are further analyzed.

Average angles of coseismic slip $(\bar{\psi})$ with respect to the trench normal and average plate convergence obliquity $(\bar{\gamma})$ for each zone along the coast are presented in Table 1. According to Fig. $6 \psi$-angles mainly vary in the range $-20^{\circ}$ to $20^{\circ}$ increasing to the southeast along the coast. Convergence obliquity $\gamma$ also grows from northwest to southeast. There are average differences of $\pm 10^{\circ}$ in $\psi$ angle values for the local catalog and the selected Global CMT thrust events.

The mean slip rate $\left(\bar{V}_{\mathrm{ss}}\right)$ of the forearc sliver relative to the fixed NA plate is $10 \pm 1 \mathrm{~mm} /$ year for the local cata$\log$ in the area $-102.0^{\circ} \mathrm{E}$ to $-97.0^{\circ} \mathrm{E}$. The average trenchparallel slip rate $\left(\bar{V}_{\mathrm{ss}}\right)$ estimated for the Global CMT catalog is $5.6 \pm 0.8 \mathrm{~mm} /$ year for the same area. These results might have been influenced by the method of average coseismic slip estimation with weights assigned to events of higher seismic moment. The local catalog includes smaller earthquakes of $M_{\mathrm{w}}=2.9-4.7$, while the Global CMT catalog has a significant number of big events and lacks seismicity below $M_{\mathrm{w}}=4.7$

Two datasets used in this study have certain differences. The local catalog has fewer earthquakes (53 events) than the Global CMT compilation (83 events). Besides, the local catalog includes events with $M_{\mathrm{w}}<4$ and has only one major event, $M_{\mathrm{w}}=7.2$ (see Additional file 1). For this catalog, the earthquakes of smaller magnitude contribute to relatively higher $V_{\mathrm{ss}}$ (Fig. 7). The slip vector of major and great events is more oblique; therefore, $V_{\mathrm{ss}}$ is smaller. For example, $V_{\text {ss }}$ estimated for the Petatlan earthquake $M_{\mathrm{w}}=7.2$ on 18 April 2014 is relatively small in both catalogs $(7.7 \mathrm{~mm} /$ year for Global CMT and $6.7 \mathrm{~mm} /$ year for the local catalog).

Comparison of focal mechanism parameters (strike, dip and rake) for the same events in teleseismic and local data reveals systematic differences (Fig. 8). These inconsistencies can be attributed to the methods of determining focal mechanisms using different datasets. In case of the Global CMT catalog, the double couple model is only part of the full tensor solution, while the focal mechanisms in the local catalog were obtained assuming perfect double couple model. Therefore, the surface

Table 1 Average plate convergence obliquity $(\bar{\gamma})$, subduction obliquity $(\bar{\psi})$ and $\bar{V}_{\mathrm{ss}}$-sinistral motion of the Xolapa sliver with restect to the fixed NA plate

\begin{tabular}{|c|c|c|c|c|c|c|}
\hline Zones & Longitude, ${ }^{\circ} \mathrm{E}$ & Latitude, ${ }^{\circ} \mathrm{N}$ & $\bar{\gamma}^{\circ}{ }^{\circ}$ & $\bar{\psi}, \circ$ & $\bar{V}_{\mathrm{ss}}, \mathrm{mm} /$ year & $\begin{array}{l}\text { Number } \\
\text { of events }\end{array}$ \\
\hline \multicolumn{7}{|c|}{ Local catalogs } \\
\hline 1 & -101.49 & 16.79 & 10.42 & $1.3 \pm 1.5$ & $9 \pm 2$ & 11 \\
\hline 2 & -100.04 & 16.26 & 11.62 & $1.7 \pm 1.9$ & $11 \pm 2$ & 22 \\
\hline 3 & -97.98 & 15.57 & 13.29 & $6.1 \pm 1.4$ & $9 \pm 2$ & 20 \\
\hline \multicolumn{7}{|c|}{ Global CMT } \\
\hline 1 & -101.49 & 16.79 & 10.42 & $2.8 \pm 1.3$ & $7.70 \pm 1.25$ & 13 \\
\hline 2 & -100.04 & 16.26 & 11.62 & $6.0 \pm 1.2$ & $6.03 \pm 1.26$ & 26 \\
\hline 3 & -97.98 & 15.57 & 13.29 & $9.1 \pm 1.0$ & $4.75 \pm 1.19$ & 44 \\
\hline
\end{tabular}



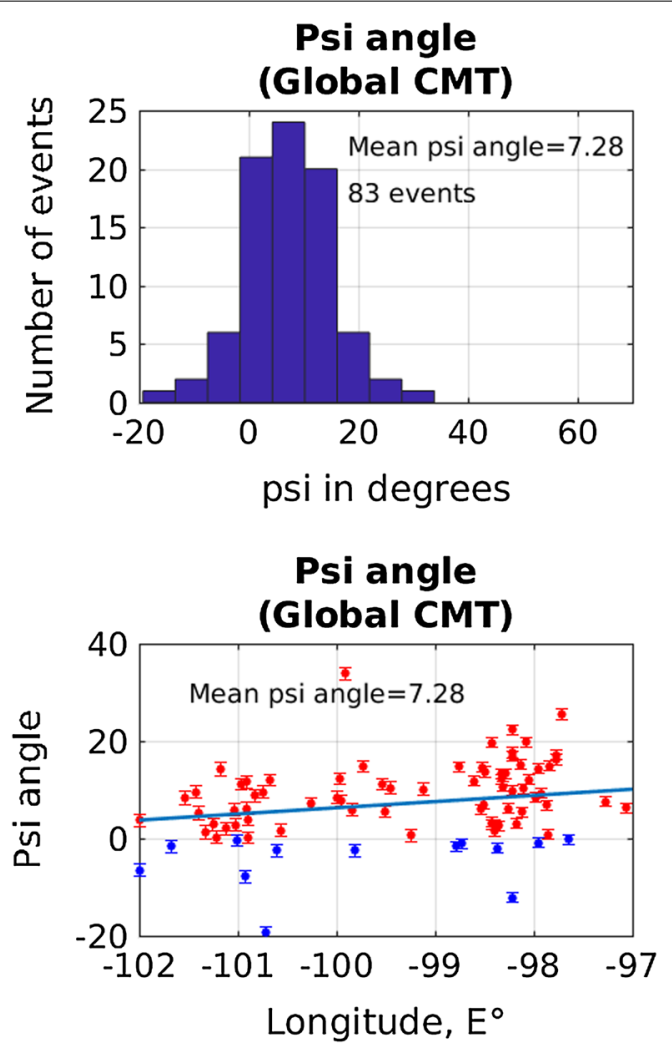
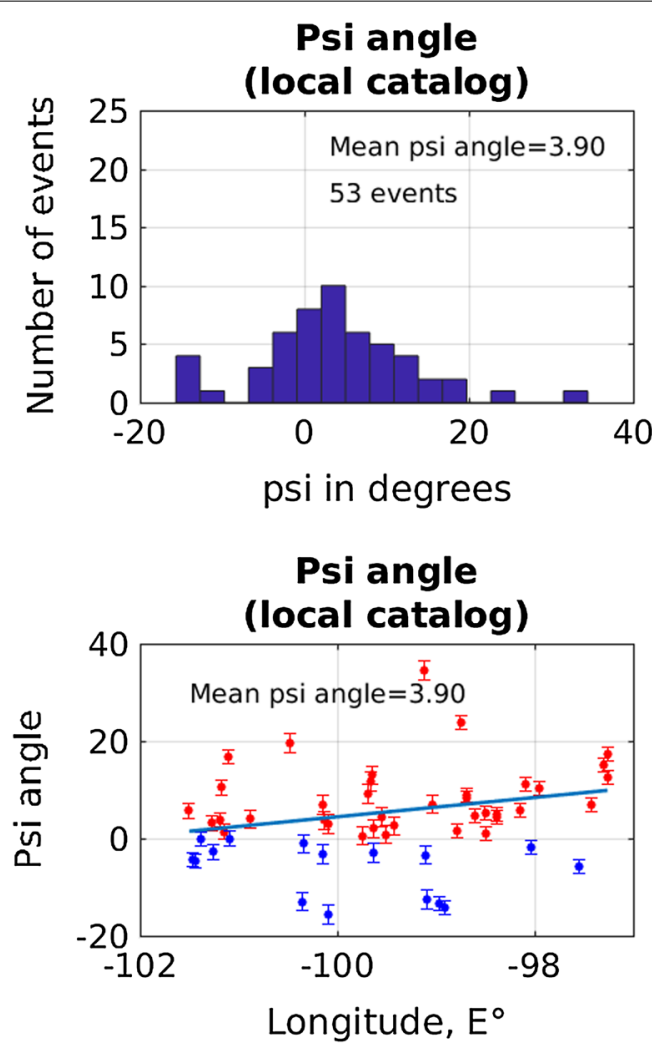

Fig. $6 \psi$-angles. Histogram of $\psi$-angles and $\psi$-angles with respect to longitude, based on data from publications of Pacheco and Singh (2010), Yamamoto et al. (2013), Pacheco et al. (2005) and the catalog of the SSN (referred as local catalog), and from selected Global CMT solutions. Red circles are positive $\psi$-angles, blue circles-negative $\psi$-angles

projection of earthquake slip vectors $V_{\mathrm{s}}$ does not show identical results for the same events. This explains partly the difference in estimations of $V_{\mathrm{ss}}$ for these two catalogs. According to Hjörleifsdóttir et al. (2016), local and global catalogs for earthquakes in the Mexican subduction zone also present differences in epicentral locations. This phenomenon is attributed to systematic patterns in the velocity structure of the mantle, with consistently fast paths to the northeast and relatively slow paths towards the southwest. The errors are found to be larger for shallowly dipping thrust events close to the trench (Hjörleifsdóttir et al. 2016), that significantly contribute to our selected datasets.

Depending on the depth of the subduction thrust earthquakes different $V_{\mathrm{ss}}$ may be expected. It can also be assumed that the larger $V_{\text {ss }}$ results from major magnitude earthquakes. However, the observations show that the extreme values of $V_{\mathrm{ss}}(33.33 \mathrm{~mm} /$ year-10 May 2014, $M_{\mathrm{w}}=5.0$, Tecpan, Global CMT catalog; -28.23 mm/year-12 July 1998, $M_{\mathrm{w}}=5.5$, Acapulco, Global CMT catalog) were obtained for moderate earthquakes with epicenters at 72 and $56 \mathrm{~km}$ from the trench. Major and great earthquakes produce $V_{\mathrm{ss}}<17 \mathrm{~mm} /$ year while the biggest contribution to the strike-slip trench parallel motion corresponds to moderate events (Fig. 7). Nonuniformity in the dataset of strike-slip vectors shows that the Xolapa sliver may present significant internal deformation. Some of its zones possibly undergo extension and others compression due to the difference in interplate coupling and geometry of the subduction zone.

The entire Xolapa sliver $\bar{V}_{\text {ss }}$ tends to decrease with increasing distance from the trench (Table 2). Therefore, maximum sinistral motion of the subducting slab with respect to the overriding plate is at shallow depths. With depth, the mean vector of coseismic slip approaches the convergence direction. Noticeable changes of strike-slip motion are observed at approximately $50-$ and $100-\mathrm{km}$ distance from the trench where the latter corresponds to the location of the LVC fault system.

The value of $\bar{V}_{\text {ss }}$ varies along the coast (Table 3). This suggests that the Xolapa sliver may deform nonuniformly with a system of microblocks undergoing compression and extension. We expected to observe extension of the sliver in the zones bounding the areas of higher convergence obliquity $\gamma$. However, the results of this study show lower values of $V_{\mathrm{ss}}$ in the areas of 

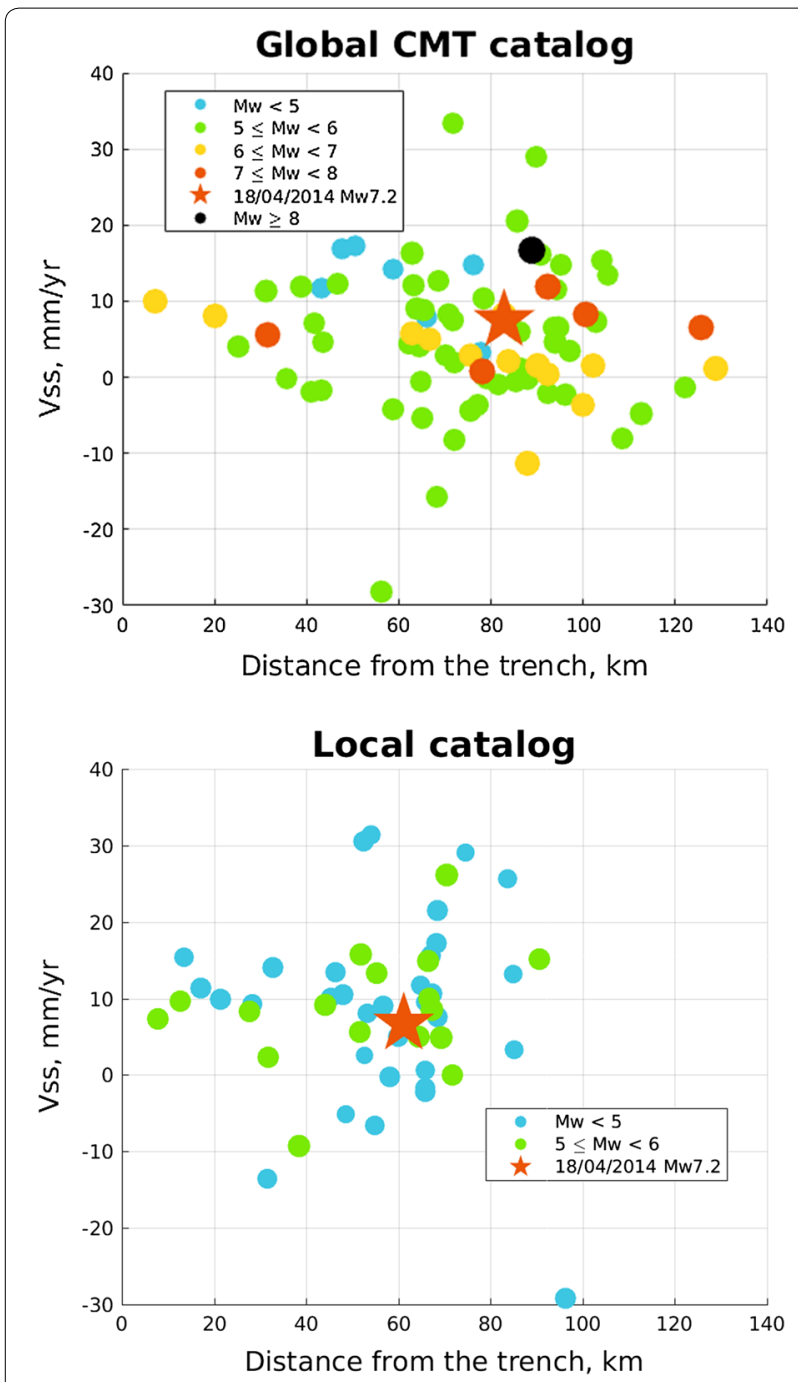

Fig. 7 Secular $V_{s s}$ as a function of the distance from the trench and $M_{\mathrm{w}}$ for Global CMT and local catalogs

increasing $\gamma$ in the southeastern part of the Xolapa sliver due to the growing angle of subduction obliquity $\psi$.

Forces acting on the sliver should be understood to explain its' motion. The Mexican subduction complex along the Guerrero-Oaxaca coast is formed by two rapidly ( $\sim 60 \mathrm{~mm} /$ year) converging tectonic plates: NA and $\mathrm{CO}$. The Xolapa sliver is a part of the forearc of the NA plate separated from the continent by the LVC fault system. Large thrust earthquakes, thrust and strike-slip slow slip events (Graham et al. 2015; Radiguet et al. 2016; Kostoglodov et al. 2016) are physical processes that take place in the study area and may affect the behavior of the sliver. Located under the northwestern part of the Xolapa sliver, the Guerrero Gap area has low long-term coupling at the seismogenic zone (Radiguet et al. 2012) that also may have an impact on the corresponding block motion.

\section{Discussion}

Estimates of the Xolapa sliver velocity $\left(V_{\mathrm{sS}}\right)$ with respect to the fixed NA plate obtained in this work using the CMT and local catalogs slip vectors in general agree with the $V_{\mathrm{ss}}$ values obtained from long-term GPS observations $\left(5-6 \mathrm{~mm} /\right.$ year). The average $V_{\mathrm{ss}}$ estimate from local catalog $(10 \pm 1 \mathrm{~mm} /$ year $)$ is higher than those from the Global CMT catalog $(5.6 \pm 0.8 \mathrm{~mm} /$ year $)$. The nature of this inconsistency is attributed mostly to a difference in the double couple focal mechanism parameters for local and teleseismic estimates. Comparison of earthquake source parameters such as strike, dip and rake for the same events shows inconsistency between local and teleseismic estimations (Fig. 8). Thus, we conclude that the resulting speed of the Xolapa sliver or the motion on the strike-slip fault calculated using the model of McCaffrey (1992) is sensitive to the type of dataset used. $V_{\mathrm{ss}}$ vary between 1 and $20 \mathrm{~mm}$ /year with the greater speed corresponding to events of smaller magnitudes $\left(M_{\mathrm{w}}<5.2\right)$. A few events in the catalogs may be misinterpreted as the subduction thrust type earthquakes on the plate interface because of not so perfect selection criteria or the error in the hypocenter depth estimates. This would result in somewhat biased values of $V_{\text {ss. }}$. Since values of $V_{\mathrm{ss}}$ obtained from Global CMT catalog are closer to the GPS estimates, it is generally more reasonable to use those data for earthquakes' slip appraisals (at least in case of Mexico). The geological estimates of the slip on the LVC fault system (4-5 mm/year of sinistral motion (Gaidzik et al. 2016)) also supports the results from the Global CMT catalog.

It is critical to make accurate calculations of the trench normal $\left(T_{\mathrm{n}}\right)$ and convergence obliquity $(\gamma)$ to obtain reliable estimates of the sliver motion $\left(V_{\mathrm{ss}}\right)$. In this study, $T_{\mathrm{n}}$ is calculated through the approximation of the Mexican trench by a small circle. Convergence obliquity $(\gamma)$ is estimated using the PVEL model which is more appropriate for the NA-CO plates convergence (DeMets et al. 2010). Convergence obliquity is observed to increase southeastward along the coast. Subduction obliquity $\psi$ shows the same tendency. As a result of the combination of these two parameters, the Xolapa sliver motion $V_{\mathrm{ss}}$ decreases from northwest to southeast. Therefore, instead of the extension regime in the area of high convergence obliquity, we would rather predict compression of the southeastern part of the sliver.

According to the rigid sliver model of McCaffrey (1992), shear forces on the subduction interface and on the crustal faults depend on the slab dip, fault depths and convergence obliquity. Notably, the convergence rate of $\sim 65 \mathrm{~mm} /$ year in Mexico is lower than in many oblique subduction zones: $\sim 91 \mathrm{~mm} /$ year in Philippines (Barrier et al. 1991), $125 \mathrm{~mm}$ /year in Western New Guinea 
Kazachkina et al. Earth, Planets and Space $\quad$ (2019) 71:104

Page 9 of 12
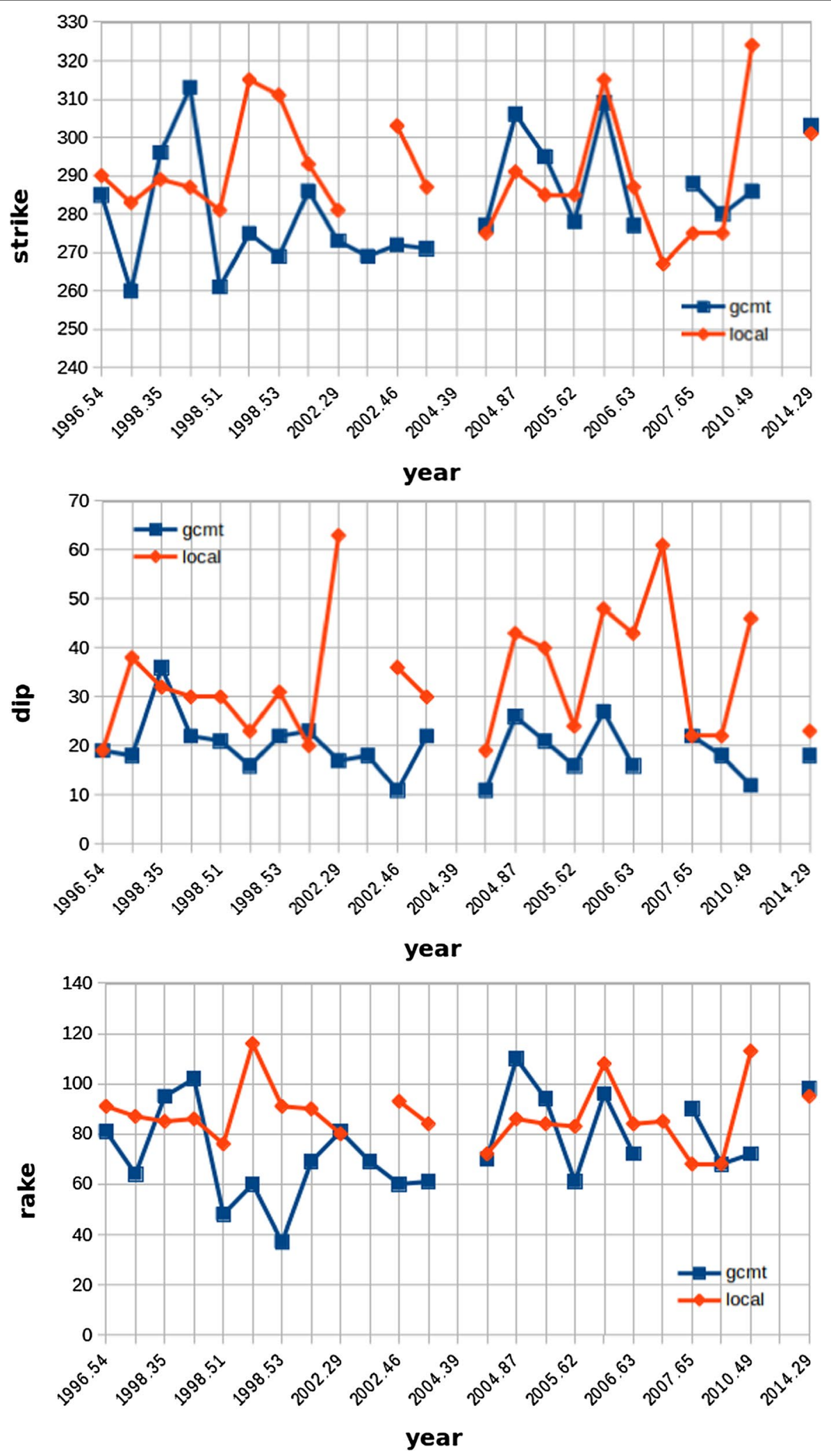

Fig. 8 Comparison of earthquake focal mechanism parameters (strike, dip, rake) for local data and Global CMT compilation 
Table 2 Mean strike-slip components of the Xolapa sliver motion $\left(\bar{V}_{s s}\right)$ for different distances from the trench calculated using data from the Global CMT

\begin{tabular}{lc}
\hline Distance $(\mathbf{k m})$ & $\overline{\boldsymbol{V}}_{\mathbf{s s}}(\mathbf{m m} /$ year $)$ \\
\hline $0-50$ & $10.2 \pm 1.6$ \\
$50-75$ & $5.4 \pm 1.8$ \\
$75-100$ & $5.4 \pm 1.5$ \\
$>100$ & $2.4 \pm 2.2$ \\
\hline
\end{tabular}

Table 3 Mean strike-slip components of the Xolapa sliver motion $\left(\bar{V}_{\text {ss }}\right)$ for the earthquakes grouped in longitude ranges, calculated using data from Global CMT compilation

\begin{tabular}{lc}
\hline Longitude ('E) & $\overline{\boldsymbol{V}}_{\text {ss }}$ (mm/year) \\
\hline-102 to -100 & $10 \pm 2$ \\
-100 to -99 & $-1 \pm 3$ \\
-99 to -98 & $6 \pm 1$ \\
-98 to -97 & $4 \pm 2$ \\
\hline
\end{tabular}

(Ekström and Engdahl 1989), $76 \mathrm{~mm} /$ year in Aleutians (McCaffrey 1992). The results of this study showed the Xolapa sliver has a speed of 5-10 $\mathrm{mm}$ /year. In comparison, there are examples of faster rates obtained with the same method: 45-60 mm/year in Sumatra, $\sim 27 \mathrm{~mm} /$ year at the Philippine trench, up to $50 \mathrm{~mm} /$ year in Aleutians (McCaffrey 1992). These subduction zones are characterized by faster convergence rates and greater obliquity.

The Xolapa sliver velocity or the slip rate at the LVC fault system obtained in this work is a product of the mean value of the oblique component of subduction thrust seismicity along the coast of Guerrero and Oaxaca. However, due to a varying degree of coupling, the sliver motion changes magnitude and direction along the trench. Apart from that, the Xolapa sliver may experience buttressing (Beck 1991) and significant along-strike variations in structure due to the presence of irregularities in its margin (Haq and Davis 2010). Several fracture zones (Orozco, O'Gorman, Tehuantepec) and seamount chains (mainly in Oaxaca) subducting below the Xolapa sliver may serve as a buttress and affect its deformation. The final displacement of the sliver needs a special tectonic analysis of its deformation. The sliver moving southeastwards at the rate of $\sim 5 \mathrm{~mm}$ /year is expected to produce some noticeable extension at its' northern edge close to Zihuatanejo and propagation of the sliver to the Gulf of Tehuantepec in the South. The translational motion of the sliver can as well be accompanied by the rotation of microblocks that makes it more complicated to evaluate its deformation. Apart from that, a prior knowledge of the sliver motion initiation is required to quantify the final sliver displacement. Thus, further modeling of the forearc deformation using GPS data and a refined fault trace mapping will lead to better understanding of the motion at the LVC fault system and associated seismic risk.

\section{Conclusions}

According to the analysis of slip partitioning in the forearc of the Mexican subduction zone using the method of McCaffrey (1992), the Xolapa sliver velocity with respect to the fixed NA plate is $10 \pm 1 \mathrm{~mm} /$ year for local catalog and $5.6 \pm 0.8 \mathrm{~mm} /$ year for Global CMT compilation. The difference between the results for two catalogs is explained by the inconsistency in local and teleseismic estimations of earthquake source parameters such as strike, dip and rake for the same events. The result from the Global CMT catalog is taken as the reference since it is in good agreement with the geologic and geodetic observations. Despite the increase of convergence velocity and obliquity to the southeast, the slip rate on the LVC fault is decreasing contrary to what would be expected. Based on this observation, we assume a compressive deformation of the Xolapa sliver likely caused by the presence of a buttressing structure, such as subducting seamount chains in Oaxaca, at its leading edge (Fig. 3). Detailed analysis of GPS time series and a refined fault trace mapping, especially in Oaxaca, will allow retrieving more information on the activity of forearc faults and associated seismic risk.

\section{Supplementary information}

Supplementary information accompanies this paper at https://doi. org/10.1186/s40623-019-1084-9.

Additional file 1. Local catalog. Thrust events compiled from publications of Pacheco and Singh (2010) (1), Yamamoto et al. (2013) (2), Pacheco et al. (2005) (3) and from the catalog of the SSN (4).

Additional file 2. Global CMT compilation. Selected thrust events from the Global CMT catalog for 1976-2016 for the events with double couple percentage $\mathrm{DC} \geq 80 \%$.

\section{Abbreviations}

LVC: La Venta-Chacalapa; NA: North America; CO: Cocos; MAT: Middle American Trench; GSF: Great Sumatran Fault.

\section{Acknowledgements}

Data from the seismic catalog of National Seismologic Service of Mexico (SSN) and Global CMT Catalog (Ekström et al. 2012) were used in this study. The figures are made with Generic Mapping Tools (Wessel and Smith 1998).

\section{Authors' contributions}

EK analyzed the data and wrote the text; VK managed the study and analyzed the data; $\mathrm{AH}$ corrected the results and text; NC analyzed the data. All authors read and approved the final manuscript. 


\section{Funding}

The authors acknowledge financial support from the PAPIIT IG100617 and CONACYT 284212 projects.

\section{Availability of data and materials}

All data generated or analysed during this study are included in this published article and its additional information files.

\section{Competing interests}

The authors declare that they have no competing interests.

\section{Author details}

${ }^{1}$ Institute of Geophysics, National Autonomous University of Mexico, Mexico City, Mexico. ${ }^{2}$ University Grenoble Alpes, Grenoble, France.

Received: 22 May 2019 Accepted: 28 September 2019 Published online: 15 October 2019

\section{References}

Barrier E, Huchon P, Aurelio M (1991) Philippine fault: a key for Philippine kinematics. Geology 19(1):32-35

Beck ME (1991) Coastwise transport reconsidered: lateral displacements in oblique subduction zones, and tectonic consequences. Phys Earth Planet Inter 68(1-2):1-8

Campa MF, Coney PJ (1983) Tectono-stratigraphic terranes and mineral resource distributions in Mexico. Can J Earth Sci 20:1040-1051

Cembrano J, Hervé F, Lavenu A (1996) The Liquiñe Ofqui fault zone: a long-lived intra-arc fault system in southern Chile. Tectonophysics 259(1-3):55-66

Cerca M, Ferrari L, López-Martínez M, Martiny B, Iriondo A (2007) Late cretaceous shortening and early tertiary shearing in the central Sierra Madre del Sur, southern Mexico: insights into the evolution of the CaribbeanNorth American plate interaction. Tectonics 26:1-34

Corona-Chávez P, Poli S, Bigioggero B (2006) Syn-deformational migmatites and magmatic-arc metamorphism in the Xolapa Complex, southern Mexico. J Metamorph Geol 24:169-191. https://doi.org/10.111 1/j.1525-1314.2006.00632.x

DeMets C (1992) Oblique convergence and deformation along the Kuril and Japan trenches. J Geophys Res 97(B12):17615-17625

DeMets C, Gordon RG, Argus DF (2010) Geologically current plate motions. Geophys J Int 181:1-80

Diament M, Harjono H, Karta K, Deplus D, Dahrin D, Zen M, Gérard M, Lassal O, Martin A, Malod A (1992) Mentawai fault zone off Sumatra: a new key to the geodynamics of western Indonesia. Geology 20:259-262

Ego F, Ansan V (2002) Why is the Central Trans-Mexican Volcanic Belt (1020-990W) in transtensive defomation? Tectonophysics 359(1-2):189-208

Ego F, Sébrier M, Lavenu A, Yepes H, Egues A (1996) Quaternary state of stress in the northern Andes and the restraining bend model for the Ecuadorian Andes. Tectonophysics 259(1-3):101-116

Ekström G, Engdahl E (1989) Earthquake source parameters and stress distribution in the Adak Island Region of the Central Aleutian Islands, Alaska. J Geophys Res 94:15499-15519

Ekström G, Nettles M, Dziewonski AM (2012) The global CMT project 20042010: centroid-moment tensors for 13,017 earthquakes. Phys Earth Planet Inter 200-201:1-9. https://doi.org/10.1016/j.pepi.2012.04.002

Gaidzik K, Ramirez-Herrera MT, Kostoglodov V (2016) Active crustal faults in the Forearc region. Guerrero sector of the Mexican subduction zone. Pure Appl Geophys 173:3419-3443

Graham S, DeMets C, Cabral-Cano E, Kostoglodov V, Rousset B, Walpersdorf A, Cotte N, Lasserre C, McCaffrey R, Salazar-Tlaczani L (2015) Slow slip history for the Mexico subduction zone: 2005 through 2011. Pure Appl Geophys. https://doi.org/10.1007/s00024-015-1211-x

Haq SSB, Davis DM (2010) Mechanics of fore-arc slivers: insights from simple analog models. Tectonics 29:TC5015. https://doi.org/10.1029/2009T C002583

Hayes G (2018) Slab2 - a comprehensive subduction zone geometry model: U.S. Geological Survey data release. https://doi.org/10.5066/F7PV6JNV
Hjörleifsdóttir V, Krishna Singh S, Husker A (2016) Differences in epicentral location of Mexican earthquakes between local and global catalogs: an update. Geofísica Internacional 55(1):79-93

Kanjorski NM (2003) Cocos plate structure along the middle America subduction zone off Oaxaca and Guerrero, Mexico. Influence of subducting plate morphology on tectonics and seismicity, University of California, San Diego

Keppie JD (2004) Terranes of Mexico revisited: a 1.3 billion year odyssey. Int Geol Rev 46:765-794

Kimura G (1986) Oblique subduction and forearc tectonics of the collision: Kuril arc. Geology 14:404-407

Kostoglodov V, Bandy W, Cominguez J, Mena M (1996) Gravity and seismicity over the Guerrero seismic gap, Mexico. Geophys Res Lett 23:3385-3388

Kostoglodov V, Husker AL, Santiago JA, Cotte N, Walpersdorf A (2016) Slow slip events on the strike slip fault in Guerrero, Mexico. In: Paper presented at the AGU Chapman Conference, Ixtapa, Guerrero, Mexico, 21-25 February 2016

Manea VC, Manea M, Kostoglodov V, Currie CA, Sewell G (2004) Thermal structure, coupling and metamorphism in the Mexican subduction zone beneath Guerrero. Geophys J Int 158:775-784

Manea M, Manea VC, Ferrari L, Kostoglodov V, Bandy W (2005) Tectonic evolution of the Tehuantepec ridge. Earth Planet Sci Lett 238:64-77

Manea M, Yoshioka S, Manea VC (2017) Subduction of oceanic plate irregularities in South-Central Mexico and the influence on subduction seismicity. Technical report, Research Center for Urban Safety and Security, Kobe University

McCaffrey R (1992) Oblique plate convergence, slip vectors, and forearc deformation. J Geophys Res 97(B6):8905-8915

Ortega-Gutiérrez F, Elías-Herrera M, Morán-Zenteno DJ, Solari L, Luna-González $L$, Schaaf $P$ (2014) A review of batholiths and other plutonic intrusions of Mexico. Gondwana Res 26(3):834-868. https://doi.org/10.1016/j. gr.2014.05.002

Pacheco JF, Singh SK (2010) Seismicity and state of stress in Guerrero segment of the Mexican subduction zone. J Geophys Res 115:B01303. https://doi. org/10.1029/2009JB006453

Pacheco J, Jiménez C, Pérez Santana J, Estrada J, Cruz J, Cárdenas A, Li Yi T, Gutiérrez M, Rubí B, Santiago J (2005) Sismicidad del centro y sur de México. (Periodo enero a junio, 2004). Geos 24(3):457-461

Pardo M (1995) Shape of the subducted Rivera and Cocos plates in southern Mexico: Seismic and tectonic implications. J Geophys Res 100(B7):12357-12373

Pérez-Campos X, Kim Y, Husker A, Davis PM, Clayton RW, Iglesias A, Pacheco JF, Singh SK, Manea VC, Gurnis M (2008) Horizontal subduction and truncation of the Cocos Plate beneath Central Mexico. Geophys Res Lett 35:L18303. https://doi.org/10.1029/2008GL035127

Pérez-Gutiérrez R, Solari L, Gómez-Tuena A, Martens U (2009) Mesozoic geologic evolution of the Xolapa migmatic complex north of Acapulco, southern Mexico: implications for paleogeographic reconstructions. Revista Mexicana de Ciencias Geológicas 26(1):201-221

Radiguet M, Cotton F, Vergnolle M, Campillo M, Walpersdorf A, Cotte N, Kostoglodov V (2012) Slow slip events and strain accumulation in the Guerrero gap, Mexico. J Geophys Res 117(4):1-13

Radiguet M, Perfettini H, Cotte N, Gualandi A, Valette B, Kostoglodov V, Lhomme T, Walpersdorf A, Cabral Cano E, Campillo M (2016) Triggering of the 2014 Mw7.3 Papanoa earthquake by a slow slip event in Guerrero, Mexico. Nat Geosci 9:829-833

Riller U, Ratschbacher L, Frisch W (1992) Left-lateral transtension along the Tierra Colorada deformation zone, northern margin of the Xolapa magmatic arc of southern Mexico. J S Am Earth Sci 5:237-249

Ryan FD, Scholl WD (1989) The evolution of forearc structures along an oblique convergent margin, central Aleutian Arc. Tectonics 8(3):497-516

Sedlock RL, Ortega-Gutiérrez F, Speed RC (1993) Tectonostratigraphic terranes and tectonic evolution of Mexico. Geological Society of America Special Paper 278

Solari LA, Torres de Leon R, Hernandez Pineda G, Sole J, Solis-Pichardo G, Hernandez-Trevino T (2007) Tectonic significance of CretaceousTertiary magmatic and structural evolution of the northern margin of the Xolapa Complex, Tierra Colorada area, southern Mexico. GSA Bull 119(9/10):1265-1279

Tolson G (2005) La falla Chacalapa en el sur de Oaxaca. Bol Soc Geol Mex 57:111-122 
Villegas-Lanza JC, Chlieh M, Cavalié O, Tavera H, Baby P, Chire-Chira J, Nocquet J-M (2016) Active tectonics of Peru: Heterogeneous interseismic coupling along the Nazca megathrust, rigid motion of the Peruvian Sliver, and Subandean shortening accommodation. J Geophys Res Solid Earth. https ://doi.org/10.1002/2016JB013080

Wang K, Hu Y, Bevis M, Kendrick E, Smalley R, Vargas RB, Lauría E (2007) Crustal motion in the zone of the 1960 Chile earthquake: detangling earthquake-cycle deformation and forearc-sliver translation. Geochem Geophys Geosyst 8:Q10010. https://doi.org/10.1029/2007GC001721

Wessel P, Smith WHF (1998) New, improved version of Generic Mapping Tools released. EOS Trans Am Geophys Union 79(47):579
Yamamoto J, Gonzalez-Moran T, Quintanar L, Zavaleta AB, Zamora A, Espindola VH (2013) Seismic patterns of the Guerrero-Oaxaca, Mexico region, and its relationship to the continental margin structure. Geophys J Int 192:375-389

\section{Publisher's Note}

Springer Nature remains neutral with regard to jurisdictional claims in published maps and institutional affiliations.

\section{Submit your manuscript to a SpringerOpen ${ }^{\circ}$ journal and benefit from:}

- Convenient online submission

- Rigorous peer review

- Open access: articles freely available online

- High visibility within the field

- Retaining the copyright to your article

Submit your next manuscript at $\boldsymbol{\nabla}$ springeropen.com 